\title{
Radiological impact of using forest tree biomass for energy and recycling the ash
}

\author{
A.H. Rantavaara ${ }^{1}$ and L.J. Aro ${ }^{2}$ \\ ${ }^{1}$ Radiation and Nuclear Safety Authority (STUK), PO Box 14, 00881 Helsinki, Finland \\ ${ }^{2}$ Finnish Forest Research Institute (METLA), Parkano Research Unit, 39700 Parkano, Finland
}

\begin{abstract}
In Northern Europe the use of tree biomass for production of energy is mostly based on thinning of forests, harvest residues, stumps from final cutting, bark of commercial roundwood, and organic waste of pulp industry. Results based on field experiments allow estimations of ${ }^{137} \mathrm{Cs}$ activity removed from forests in wood fuel, and also the activity returned in ash used as a fertiliser. After one fertilisation treatment in three types of coniferous forests the activity concentration of ${ }^{137} \mathrm{Cs}$ in wood fuel and ash was reduced to a fraction of 0.3 to 08 of activities in products from unfertilised forests. The improved tree growth and lowering activity concentrations of ${ }^{137} \mathrm{Cs}$ in trees and understorey after fertilisation refer to reduction of human radiation exposure in Chernobyl-affected areas in the long term. Thereby radiation doses to workers handling the ash and members of the public using forests will gradually decrease faster than through radioactive decay only. A documented and traceable ash recycling history of forests is important for all users of forests.
\end{abstract}

\section{INTRODUCTION}

Today the resources of fuel for bioenergy production are extensively studied due to the increasing cost of energy and the common goal to reduce atmospheric emissions of greenhouse gases from combustion of fossil fuels. In Finland forests provide a considerable resource of biofuel in the form of thinning and harvest residues, stumps and roots. Currently, logging residues received from thinning, final cutting of stands, and stump harvesting are of prime importance to the delivery of wood fuel from forests [1, 2]. In Finland, the annual harvest potential of forest biomass for energy was estimated to be 15.9 million $\mathrm{m}^{3}$ in 2004 [1]. Forest industry also uses significant amounts of bark of roundwood, and waste liquors and other by- and waste products for energy.

The composition of available tree biomass for fuel varies by tree species, site conditions, and development stage of a stand. During rotation period a spruce stand doubles the yield of wood fuel compared to pine and birch stands, representing almost half of the total output. The nutrient removal from forests in wood fuel and commercial logs may have negative effects on tree growth during next tree generation [1]. The need to compensate nutrient losses has long been of interest from the forest management point of view [3], and also a radioecological issue after the Chernobyl accident in 1986.

Environmental radionuclides of natural and artificial origin are found in forests, and in boreal forests their uptake from soil to vegetation can be higher than in agricultural areas or in more favourable growth conditions elsewhere in northern hemisphere forests. Radionuclides are found in all main compartments of forests, as soil, humus and litter, trees, bushes, understorey vegetation, and fauna. Artificial radionuclides ${ }^{90} \mathrm{Sr},{ }^{137} \mathrm{Cs}$ and ${ }^{239,240} \mathrm{Pu}$ from nuclear weapons tests are still available to plants. These radionuclides deposited in Finland also after the Chernobyl accident in 1986, but only for

${ }^{137} \mathrm{Cs}$ the later contamination exceeds the activity of global nuclear fallout accumulated in ground and ecosystems.

Radionuclide content of forest biomass harvested for energy, and human exposure in the chain of bioenergy production are related via the wood ash. The ash is decisive to the radiation exposure of 
workers handling the ash. The public using forests will mostly be exposed to radionuclides through ingestion of wild foods. In the long term, the doses to public will be highest on radioactively contaminated sites where the nutrient losses following biofuel harvesting have not been compensated, and lowest on fertilised sites, where the satisfactory mineral nutrient status of forest will maintain the uptake of ${ }^{137} \mathrm{Cs}$ low, and even reduce it.

Several field experiments established in 1980's or earlier have provided data on the effect of mineral and ash fertilisation on ${ }^{137} \mathrm{Cs}$ contamination of forest vegetation, particularly trees [4-8]. In all field experiments fertilised stands and unfertilised, or control stands, were analysed. These studies have given evidence for reduction in uptake of ${ }^{137} \mathrm{Cs}$ by trees and understorey after treatment of forest floor with potassium containing ash or mineral fertiliser. This is because potassium in ash ( $\mathrm{K}$ concentration in wood ash 1.4-2.3\%) [1] reduces the root uptake of ${ }^{137} \mathrm{Cs}$ by plants, regardless of the origin of ${ }^{137} \mathrm{Cs}$. Therefore the reduction is significant for the ${ }^{137} \mathrm{Cs}$ accumulated earlier in soil and the soluble ${ }^{137} \mathrm{Cs}$ in ash used as a fertiliser. The effect of fertilisation appears slowly, during several years and lasts long [8]. Fertilisation can also increases tree growth significantly, thus providing a profitable tool for managing forests contaminated from atmospheric deposition of ${ }^{137} \mathrm{Cs}[9]$.

Our study aimed to clarify the effect of the use of forest biomass for energy on the distribution and inventory of ${ }^{137} \mathrm{Cs}$ in coniferous forests. Human exposure to radiation may be changed in the process of sequential harvesting of fuel, and the tendency towards lower or higher radiation doses is possible, depending on forest management. We discuss doses received by the public from the use of fertilised forests, and radiation exposure of workers from handling and transport of wood ash.

\section{MATERIAL AND METHODS}

\subsection{Data from fertilisation experiments}

A new data set for harvest residuals of a mature Norway spruce (Picea abies) stand on grove-like site in southern Finland (mean stand volume $414 \mathrm{~m}^{3} \mathrm{ha}^{-1}$ ) was of interest for comparison with Scots pine, and the effect of fertilisation on trees on a fertile site. Harvest residuals were sampled after final felling of the stand. The fresh mass of the logging residuals was weighted in the field, and dry matter content was determined by drying at $+60^{\circ} \mathrm{C}$ in a laboratory for a few days before determining the activity concentrations of ${ }^{137} \mathrm{Cs}$ (Table 1).

Table 1. Fertilisation experiment on a mature Norway spruce stand on grove-like mineral soil, sampled in connection of final felling thirteen years after the treatment. Biomass (DM) and ${ }^{137} \mathrm{Cs}$ concentration in harvest residuals and the effect of fertilisation as a ratio F/C, referring to ${ }^{137} \mathrm{Cs}$ concentration in samples from fertilised and control stands.

\begin{tabular}{|l|c|c|c|c|c|}
\hline \multirow{2}{*}{ Treatments } & \multicolumn{2}{|c|}{$\begin{array}{c}\text { DM of harvest residuals } \\
\mathrm{kg} / \mathrm{ha}\end{array}$} & \multicolumn{3}{|c|}{${ }^{137} \mathrm{Cs}(\mathrm{Bq} / \mathrm{kg}$ DM) } \\
\cline { 2 - 6 } & Needles & Branches & Harvest residuals & Needles & Branches \\
\hline $\begin{array}{l}\text { No fertilisation } \\
\text { (control) }\end{array}$ & 12080 & 30480 & 730 & $745 \pm 5 \%$ & $726 \pm 3 \%$ \\
\hline $\begin{array}{l}\text { NPK + trace: } \\
\text { N 180, P 40 and K }\end{array}$ & 15960 & 43950 & $F / C: 0.50$ & $F / C: 0.49$ & F/C:0.51 \\
$120 \mathrm{~kg} / \mathrm{ha}$
\end{tabular}

Data from two field experiments where the latest treatments of Scots pine stands were from 1980's were used in estimation of activities in wood fuel and ash. All stands had experimental plots both on fertilised sites and on unfertilised sites, with two replications. The wood fuel we assessed composed of branches, bark of roundwood, stumps and roots, and optionally needles and leaves [5-7]. The advanced 
Table 2. Description of the two experiments providing data for wood fuel assessments [5-7]. Effect of fertilisation on activity concentration of ${ }^{137} \mathrm{Cs}$ in dried $\left(60^{\circ} \mathrm{C}\right)$ wood fuel and ash is given as a ratio F/C ('fertilised' to 'control').

\begin{tabular}{|l|c|c|}
\hline \multicolumn{1}{|c|}{$\begin{array}{c}\text { Site and stand type } \\
\text { Treatment }\end{array}$} & Tree parts included in wood fuel & F/C \\
\hline $\begin{array}{l}\text { Subdry site on mineral soil: } \\
\text { Advanced thinning stand of Scots pine }\end{array}$ & $\begin{array}{c}\text { 1. Branches, bark and phloem of } \\
\text { roundwood, stumps and coarse roots }\end{array}$ & 0.31 \\
\cline { 1 - 1 } $\begin{array}{l}\text { NPK + NPK: N 180, P 80, K 300 kg/ha } \\
17 \text { and 12 years before sampling }\end{array}$ & 2. As in 1. but including needles & 0.28 \\
\cline { 1 - 2 } $\begin{array}{l}\text { Drained forested peatland: } \\
\text { Advanced thinning stand of Scots pine } \\
\text { with birch mixture }\end{array}$ & $\begin{array}{c}\text { 1. Branches, bark and phloem of } \\
\text { roundwood, stumps and coarse roots }\end{array}$ & 0.47 \\
\cline { 1 - 1 } $\begin{array}{l}\text { PK + K: P 55, K 96 kg/ha 21 years, and } \\
\text { K 80 kg/ha 8 years before sampling }\end{array}$ & 2. As in 1. but including needles & 0.46 \\
\hline
\end{tabular}

thinning stands were dominated by Scots pine, one on sub-dry mineral soil site and the other on drained peatland, where also birch contributed to wood fuel (Table 2).

Tree dimensions of Scots pine were measured at sample tree harvest, and using this data, biomass of different tree parts was estimated with plot specific models [7]. Thus the activity of ${ }^{137} \mathrm{Cs}$ in various components of tree biomass used for fuel was possible to report also as activity content of wood fuel per unit of surface area of forest. We considered ${ }^{137} \mathrm{Cs}$ activity and biomass in various tree fractions of Scots pine (Pinus sylvestris) and, on peatland site, understory birches (Betula pendula, B. pubescens) [5-7].

\subsection{Calculation of ${ }^{137} \mathrm{Cs}$ activity in wood fuel ash}

For two experimental forests of Scots pine the reduction in ${ }^{137} \mathrm{Cs}$ activity of wood fuel and in ash from such fuel was estimated. The ash content of wood fuels was estimated for wood fuel according to composition of fuel, considering earlier laboratory studies for the so called 'clean ash' content in dried needles and woody components of fuel $[10,11]$. The additional inorganic component of ash from combustion of wood at energy production plants was approximated [10-13]. Thereby the content of ${ }^{137} \mathrm{Cs}$ in a dose of ash to be used for fertilisation was obtained. Application rate was $3000 \mathrm{~kg}$ ash per hectare according to the recommendations for upland forest soils [1], and the same amount of ash was also used in the assessment for peatland forest. Reduction in activity concentrations due to fertilisation and the effect of wood fuel harvesting and ash recycling on the activity inventory of ${ }^{137} \mathrm{Cs}$ in two types of Scots pine forests was estimated.

\section{RESULTS AND CONCLUSIONS}

\subsection{Concentration of ${ }^{137} \mathrm{Cs}$ in wood fuel and ash}

In all three fertilisation studies the activity concentration of ${ }^{137} \mathrm{Cs}$ in wood fuel decreased after mineral or ash fertilisation (Tables 1 and 2). The decrease in activity in fuels from fertilised sites was half of the activity on control site in samples of harvest residuals from a mature Norway spruce stand from grove-like site and in wood fuel from an advanced thinning stand of Scots pine (with a minor mixture of birch) on peatland, assessed from activities in parts of trees contributing to wood fuel. Advanced Scots pine stand on sub-dry site had been applied with a high dose of potassium (K), which reduced the ${ }^{137} \mathrm{Cs}$-activity in wood fuel most, to $30 \%$ of the activity concentration in unfertilised forest. Compared to mineral soil site, on peatland the effect of fertilisation was lower due to the smaller amounts of nutrients applied in relation to nutrient status of the stand, though the amounts of nutrients were in accordance with the recommendations for peatland forestry. The lowest dose of $\mathrm{K}$ was used in ash application of a 
mature Norway spruce stand on fertile mineral soil, and the activity of harvest residuals reduced to only $80 \%$ in branches and $70 \%$ in needles compared to unfertilised stands (Table 1).

The time period between the latest treatments of the stands and sampling ranged from eight to thirteen years in the three studies. The effect of fertilisation was still roughly proportional to the dose of $\mathrm{K}$ in fertilisation. In both experiments of Scots pine the reduction of activity due to fertilisation was significant in all tree parts [5-7], whereas the significance of the reduction of ${ }^{137} \mathrm{Cs}$ in harvest residuals of Norway spruce was not possible to test due to insufficient number of replications after final felling.

For both types of Scots pine forests the fraction of ${ }^{137} \mathrm{Cs}$ inventory of the site was assessed for wood fuels, whole trees representing the total biomass removed from forest, and doses of ash from two types of fuel (Fig. 1). Needles were considered as an optional component of wood fuel. Excluding needles and leaves from fuel has been suggested to reduce nutrient losses in forests [3]. Needles did not cause considerable changes in activity concentration of wood ash, because their mass fraction in logging residuals is relatively small, and their ash content is higher than in woody parts of fuel. Recommended dose of ash, $3 \mathrm{tn} / \mathrm{ha}$, exceeds the amount of ash formed from wood fuel of the studied sites, but the dose was relevant for compensation of nutrients removed in harvesting of whole trees. For peatland a reasonable ash dose is obviously more than 3 tons/ha [1].
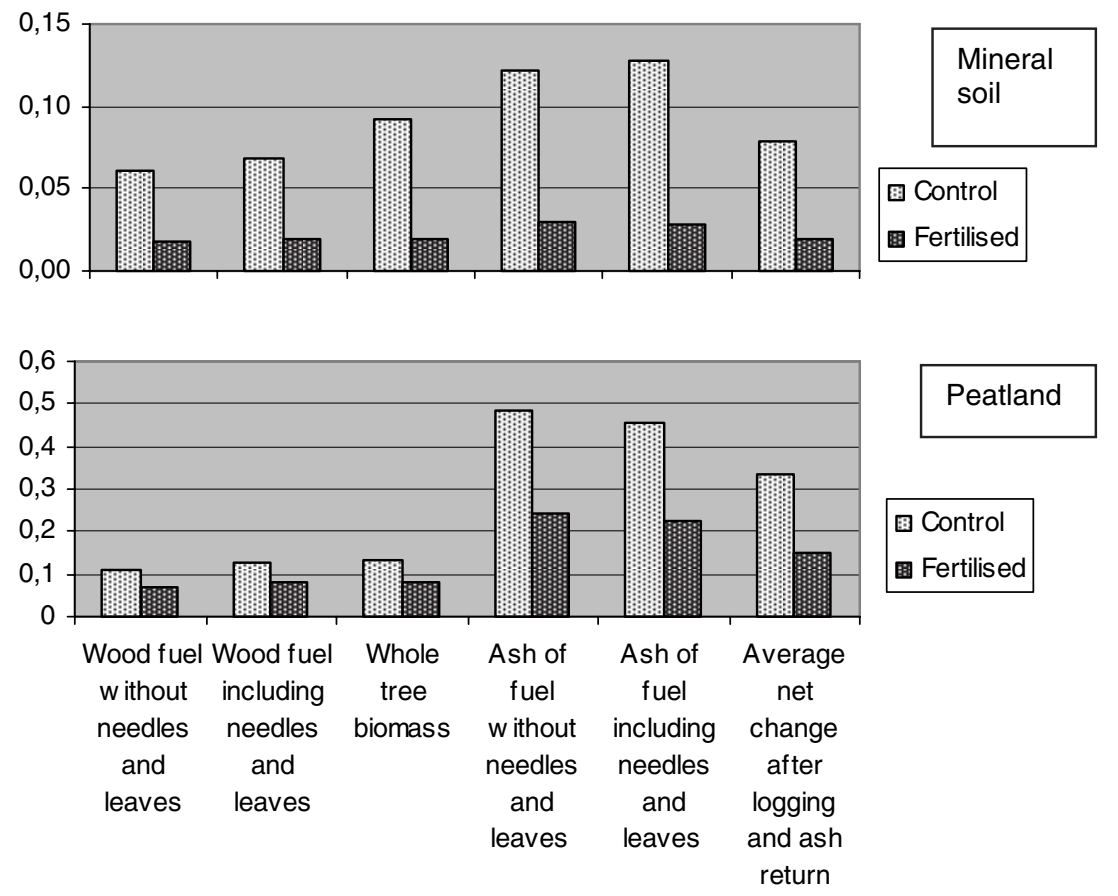

Figure 1. ${ }^{137} \mathrm{Cs}$ fractions of site inventory corresponding to site specific, optional wood fuels available after logging, and their ashes to be used for fertilisation (dose $3 \mathrm{tn} / \mathrm{ha}$ ). For net change the activity content of ${ }^{137} \mathrm{Cs}$ in the whole tree biomass was subtracted from average activity in a dose of ash. See details on experiments in Table 2.

The activity of ${ }^{137} \mathrm{Cs}$ returned to forests in ash indicates a higher uptake of ${ }^{137} \mathrm{Cs}$ from peatland to trees compared to mineral soil. In the surface area based assessment the activities in the harvested biomass, i.e. wood fuel and whole tree, differ less than activity concentrations in fuel and ash because of the higher biomass of trees on mineral soil. The net effect of wood fuel harvesting in connection of logging, and return of ash suggest addition to the ${ }^{137} \mathrm{Cs}$ inventory of the two sites after one fertilisation treatment. However, the addition is significantly lower in fertilised forests, and essential 
for human radiation exposure through forest products is the reduction in their activity concentration. Ash fertilisation will reduce activity concentration of ${ }^{137} \mathrm{Cs}$ in all plant and animal products from forests and thereby human exposure to radiation.

In forestry the ash is hardly ever returned to the same site where the wood fuel originated. Nor is the fuel from various tree fractions in one batch; bark of roundwood and forest processed chips are often transported to energy production plants through different routes. The aim of assessing ${ }^{137} \mathrm{Cs}$ activity content in wood fuel and ash corresponding to each other was to demonstrate the net effect on the ${ }^{137} \mathrm{Cs}$ inventory of forests.

\subsection{Radiation doses to the public and workers handling the ash}

Forest workers and the public using forests are exposed to gamma radiation after ash fertilisation of forests. From ash containing $10000 \mathrm{~Bq}^{137} \mathrm{Cs} \mathrm{kg}^{-1} \mathrm{DM}$ and a dose of $5 \mathrm{tn} \mathrm{ha}^{-1}$ the dose rate is less than $7 \mathrm{nGy} \mathrm{h}^{-1}$ immediately after fertilisation. Dose from ash to forest worker was $0.008 \mathrm{mSv} \mathrm{a}^{-1}$, when exposure time without shielding was $1500 \mathrm{ha}^{-1}$ [11]. In fact, most forestry work today is not without shielding. Members of the public were assumed to spend in fertilised forest $120 \mathrm{~h} \mathrm{a}^{-1}$, receiving a dose of $0.0006 \mathrm{mSv} \mathrm{a}^{-1}$. Dose rate in forest is lower than estimated because of the roughness of soil surface, and due to gradual downward migration of radionuclides of ash. Natural radionuclides in five tons of wood ash distributed per hectare caused approximately the same dose rate in air as $1000 \mathrm{~Bq}^{137} \mathrm{Cs} \mathrm{m}^{-2}$, i.e. less than $0.002 \mathrm{mSv} \mathrm{a}^{-1}$ for the forest worker [11].

In areas where wild berries and mushrooms are picked for own use the ingestion dose from ${ }^{137} \mathrm{Cs}$ dominates the radiation dose received from forests. After ash fertilisation of forests ingestion dose from wild food will be gradually reduced, as evidenced for lingonberry [14]. The reduction of internal dose from berries and mushrooms can be significantly higher than external dose from ash to pickers [11-14].

Three different wood energy plants and a mill granulating ash were surveyed for radiation exposure of workers [11]. Dose rates exceeding the background radiation at the plant were measured and exposure times approximated with workers, considering various tasks and target areas. Often the upper boundaries of doses were obtained through assuming higher than average exposure times and activity concentrations in ash. Exposure of drivers transporting ash with long-distance trucks was assessed for ash containing $10 \mathrm{kBq}^{137} \mathrm{Cs} \mathrm{kg}^{-1}$, and considering the shielding provided by truck. Doses from airborne ash dust were assessed assuming $1 \mathrm{mg} \mathrm{m}^{-3}$ air concentration of ash. For inhaled ${ }^{137} \mathrm{Cs},{ }^{90} \mathrm{Sr},{ }^{40} \mathrm{~K},{ }^{210} \mathrm{~Pb},{ }^{232} \mathrm{Th},{ }^{235} \mathrm{U}$ and ${ }^{226} \mathrm{Ra}$ the activity concentrations in wood ash from energy production were available [12, 13]. Dose estimates varied with task ranging from 0.03 to $0.45 \mathrm{mSv} \mathrm{a}^{-1}$, being highest for drivers involved in long distance transport of ash and workers of the granulating mill due to rather long exposure times. Dose estimates from inhaled ash were very low at the plants, and they can be minimised in conditions of ash spreading to forest from ground level in modern vehicles where filtered air intake and overpressure of the cabin protect the worker. Intervention dose to workers was $1 \mathrm{mSv} \mathrm{a}^{-1}$ and to members of the public $0.1 \mathrm{mSv} \mathrm{a}^{-1}$.

\subsection{Long term consequences of harvesting wood fuel and recycling the ash}

Compared to not returning nutrients to forests after harvesting of wood fuel, the wood ash returned to forests reduces contamination of trees and other vegetation as regards to several radionuclides of alkali and earth alkali metals, also through liming effect of wood ash. Reduction in solubility of most natural radionuclides, ${ }^{137} \mathrm{Cs}$ and ${ }^{90} \mathrm{Sr}$ during combustion of fuel [11-13] also contributes to the reduction of human exposure through consumption of wild food. The slowly soluble fraction of nutrients in ash continues the fertilisation effect in soil for many years. Particularly in Chernobyl-affected areas the mitigating effect of ash fertilisation on human exposure to radiation via forest products can be significant. The reason is the reduction in uptake of all ${ }^{137} \mathrm{Cs}$ available to plants in soil, not just ${ }^{137} \mathrm{Cs}$ from ash. 
Changes in human exposure through long term harvesting of tree biomass for fuel will depend on the site conditions and forest management methods applied. Either decrease, through optimised recycling of ash concerning timing and doses of wood ash, or increase of radiation exposure, if the nutrient losses due to biomass harvesting are not compensated, seems possible. To be traceable, the owners of forests should document recycling and origin of ash.

Further research and surveillance is required for a realistic view of radioecological effects of intensive wood fuel harvesting and ash recycling. Issues of further consideration might be the effects of breaking the surface of forest floor in connection of stump harvesting [1] on soil-to plant transfer of chemically different radionuclides, and the effect of ash fertilisation on micro-organisms of soil, or on species composition of ground vegetation. Wood bioenergy is expected to be produced in a sustainable way [15].

\section{References}

[1] Laitila J., Asikainen A. and Anttila P., "Energiapuuvarat", Kuusinen M. and Ilvesniemi H. (Eds.): Energiapuun korjuun ympäristövaikutukset. (Environmental effects of wood harvesting for energy). Tutkimusjulkaisuja, Tapion ja Metlan julkaisuja. Published in internet 11.2.2008, www.metsavastaa.net/energiapuu/raportti, pp. 6-12.

[2] Hynynen J., Finnish Forest Research Institute, Research Papers 816 (2001) 9-16.

[3] Mälkönen E., Kukkola M. and Finer L. Finnish Forest Research Institute, Research Papers 816 (2001) 31-52.

[4] Rantavaara A. and Aro L., STUK-A 195 (2003) 443-449.

[5] Aro L., Rantavaara A., Raitio H. and Vetikko V., Radioprotection - colloques 37 (C1) (2002) 427-432.

[6] Aro L. and Rantavaara A., 2002. " ${ }^{137}$ Cs activity in stumps and coarse roots of pine, spruce and birch trees as affected by fertilization", Proceedings from the International Conference on Radioactivity in the Environment, 1-5 September 2002 Monaco, P. Børretzen, T. Jølle, and P. Strand Eds. (2002) Posters, CD-rom appendix, 4 p.

[7] Moberg L., Hubbard L., Avila R. Wallberg L., Feoli E., Scimone M., Milesi C., Mayes B., Iason G., Rantavaara A., Vetikko V., Bergman R., Nylén T., Palo T., White N., Raitio H., Aro L., Kaunisto S. and Guillitte O. An integrated approach to radionuclide flow in semi-natural ecosystems underlying exposure pathways to man (LANDSCAPE). Final Report (Swedish Radiation Protection Institute, Stockholm, 1999) pp. 29-37.

[8] Kaunisto S., Aro L. and Rantavaara A., Environmental Pollution 117 (2002) 111-119.

[9] Rantavaara A., Aro L. and Aarnio J., "Sustainable remediation of forests after ${ }^{137} \mathrm{Cs}$ contamination", Proceedings from the International Conference on Radioactivity in the Environment, 1-5 September 2002, Monaco, P. Børretzen, T. Jølle, and P. Strand Eds. (2002) Posters, CD-rom appendix, $5 \mathrm{p}$.

[10] Hakkila, P. and Kalaja, H. Folia Forestalia 552 (1983) 1-37.

[11] Vetikko V., Valmari T., Oksanen M., Rantavaara A., Klemola S. and Hänninen R., STUK-A 200 (2004) 1-106.

[12] Rantavaara A.H. and Moring K.M. "Contaminated tree biomass in energy production - potential need for radiation protection”, Contaminated Forests, I. Linkov, W.R. Schell (Eds.): (Kluwer Academic Publishers, The Netherlands, 1999) 303-310.

[13] Rantavaara A. and Moring M. Report STUK-A 177 (2001) 1-41.

[14] Levula T., Saarsalmi A. and Rantavaara A., Forest Ecology and Management 126 (2000) 267-277.

[15] Stupak, I., Asikainen A. and Jonsell M., et al. Biomass and Bioenergy 31 (2007) 666-684. 